\title{
Assessment of Physicochemical and Microbiological Quality of Nagpuri Buffalo Raw Milk Collected at Different Areas in Nagpur City
}

\author{
L.D. Dhote ${ }^{1}$, G.J. Bidgar ${ }^{2}$, N.R. Pansare $^{2}$, K. Satyaprakash ${ }^{2}$, S.V. Shinde ${ }^{2}$, \\ S.P. Chaudhary ${ }^{2}$ A.R. Patil ${ }^{3}$ and W.A. Khan ${ }^{3}$ \\ Department of Veterinary Public Health and Epidemiology, Nagpur Veterinary College, \\ Seminaryhills, Nagpur-440006, India \\ *Corresponding author
}

\section{Keywords}

Nagpuri Buffaloes,

Vendors, Physio-

chemical,

Bacteriological commercial kit, Food-borne

Article Info

Accepted:

20 January 2019

Available Online:

10 February 2019

\section{A B S T R A C T}

Nagpuri buffalo is native to Nagpur region of Maharashtra.The Nagpuri buffaloes are moderately good milk producers. Their milk is of very good quality containing around 7.7 percent of fat. Most of the people especially children depend on local vendors for buffalo milk. Alteration in physicochemical /microbiological parameters has direct impact on the quality of milk. Growing evidence those foods borne pathogen directly or indirectly causes or predispose man to chronic diseases. The present study is conducted to analyze the physiochemical and microbiological quality of raw milk by employing clot on boiling test, California mastitis test, titrable acidity, methylene blue reduction test and again the same sample were processed for identification of differential food borne pathogen by using Himedia differential food borne pathogen commercial kit. A total of 40 different Nagpuri buffalo milk samples were collected from different areas in Nagpur city. Sample collected directly into the sterilized milk collection bottle and subjected to analysis in the laboratory. Out of 40 samples buffalo milk, 22 samples (55 per cent) shown titrable acidity more than $0.18 \%$ and five (12.5 per cent) with CMT positivity. The COB and MBRT turned negative for all the samples tested and. Total viable count is under acceptable range. By using bacteriological commercial kit, Out of total 40 samples, seven samples became positive for E. coli (17.5\%), one for Salmonella (2.5\%), one for Vibrio (2.5\%), nine for Listeria monocytogenes (22.5\%) and two for Staphylococcus aureus (5\%). In conclusion, from the above result it is concluded that the presence of pathogens in milk samples is the matter of concern from public health point of view. Further, the bacterial contamination may be contributed to less hygienic practices followed with respect to udder health management.

\section{Introduction}

India stands $1^{\text {st }}$ in the world for milk production as well as buffalo population. India continues the largest producer of milk in world by producing $165.4 \mathrm{MT}$ in 2016-2017 statistics of India. The per capita availability of the milk is $355 \mathrm{gm} /$ day and ICMR recommendation is $280 \mathrm{gm} /$ day in our country. This indicates the growth in availability of milk and milk product for every year. (Department of Animal Husbandry, Dairying 
\& Fisheries, Ministry of Agriculture, GoI 2016-2017).

Milk act as rejuvenator, has health protecting and promoting properties, hence can be referred as one of the best vitalisers and it is considered the most important part of our diet. But the greatest drawback it is perishable in nature which is responsible for the spoilage of raw milk because of that its shelf life become very less at room temperature. Number of factors are responsible, to change in the quality of milk some of the most important causes are: health of the animal, housing, sanitation along with the person involved in the production, their health, sanitary practices followed by them and finally the container in which milk is poured which is invariably contaminating and last but not the least tropical nature of climate of our country (Nalwaya et al., 2018). The Nagpuri buffalo is a very good breed of water buffalo from India. It is actually from Maharashtra, and it stands better amongst the buffalo breeds which combine the milk and drought qualities in a better proportion in adverse climatic conditions. The Nagpuri buffaloes are moderately good milk producers. As the name suggests, it is a versatile breed of the Vidarbha region (central Indian breed) of Maharashtra. They are very well adapted to the harsh-semi-arid conditions of Vidarbha region. The Nagpuri buffaloes are very good for milk production. Their average lactation period is around 286 days. And on an average, they produce minimum 1055 liters of milk per lactation. Their milk is of very good quality containing around 7.7 percent of fat.

Most of the people especially children depend on local vendors for buffalo milk. Alteration in physicochemical /microbiological parameters has direct impact on the quality of milk. Growing evidence those foods borne pathogen directly or indirectly causes or predispose man to chronic diseases. As in any raw milk, microorganisms can multiply rapidly in buffalo milk due to its high nutrient content. Previous studies on the microbiological quality of buffalo milk have revealed the presence of, e.g., coliform bacteria, Escherichia coli, lactic acid bacteria, Listeria monocytogenes, yeasts, moulds, Staphylococcus spp. and Clostridium spp. The occurrence of highly pathogenic spoilage producing bacteria might lead to the deterioration of buffalo milk and present a public health hazard (Han et al., 2007)

\section{Materials and Methods}

\section{Sample collection}

A total of 40 different Nagpuri buffalo milk samples were collected aseptically from the udder directly into sterilized milk sampling bottles from the different areas in Nagpur city.

\section{Physiochemical and microbiological analysis}

The samples were analysed for clot on boiling test, MBRT, titrable acidity, CMT and microbiological quality test ie. Total Viable Count (TVC)

\section{Microbiological analysis with commercial kit}

These samples were processed as per the guidelines in the manual of commercial kit (HiMedia) and were tested for the presence of important food-borne pathogens like E. coli, Salmonella, E. coli O157:H7, Vibrio, Staphylococcus aureus, Listeria monocytogens and Clostridium organisms.

\section{Results and Discussion}

Present study was carried out to determine physico-chemical and microbiological 
qualities of milk. The wrong milking practices, polluted water supply, defective transport, warm climate, unhygienic conditions of farms, the lack of suitable technical and educational information causes inferior quality of milk and indigenous milk products especially in unorganized sector these are the main reasons for deterioration of raw milk very early. By knowing the importance of milk in human diet, Nagpuri buffalo raw milk samples were collected to assess the physico-chemical and microbiological qualities of milk sold in the unorganized sector of Nagpur city. The results obtained were analyzed using appropriate method and presented as follows (Fig. 1-3).

\section{Physicochemical analysis}

Acidity in milk have been measured in terms of per cent lactic acid, in different samples of milk is ranged from 0.13 to 0.28 (per cent of Lactic acid bacteria) (Table 1).

Table.1 Physico-chemical and microbiological analysis of milk sample

\begin{tabular}{|l|l|l|l|l|}
\hline $\begin{array}{l}\text { Sample } \\
\text { collected }\end{array}$ & $\begin{array}{l}\text { Titrable } \\
\text { acidity }\end{array}$ & $\begin{array}{l}\text { California mastitis } \\
\text { test }\end{array}$ & Clot on boiling & $\begin{array}{l}\text { Methylene blue } \\
\text { reduction test }\end{array}$ \\
\hline $\mathbf{4 0}$ & 22 & 5 & - & - \\
\hline & $\begin{array}{l}\text { Acidity more } \\
\text { than } 0.18 \%\end{array}$ & Positive & Negative & Negative \\
\hline
\end{tabular}

Table.2 Microbiological analysis of milk sample by using differential food borne pathogen commercial kit (Himedia)

\begin{tabular}{|c|c|c|}
\hline organism & No of positive & Percentage \\
\hline E. coli & 7 & 17.5 \\
\hline Salmonella & 1 & 2.5 \\
\hline Vibrio & 1 & 2.5 \\
\hline L.monocytogenes & 9 & 22.5 \\
\hline staphylococcus & 2 & 5 \\
\hline Total & 20 & 50 \\
\hline
\end{tabular}

Fig.1\&2 CMT using strip cup \& Plate showing colonies at $10^{-4}$ dilution
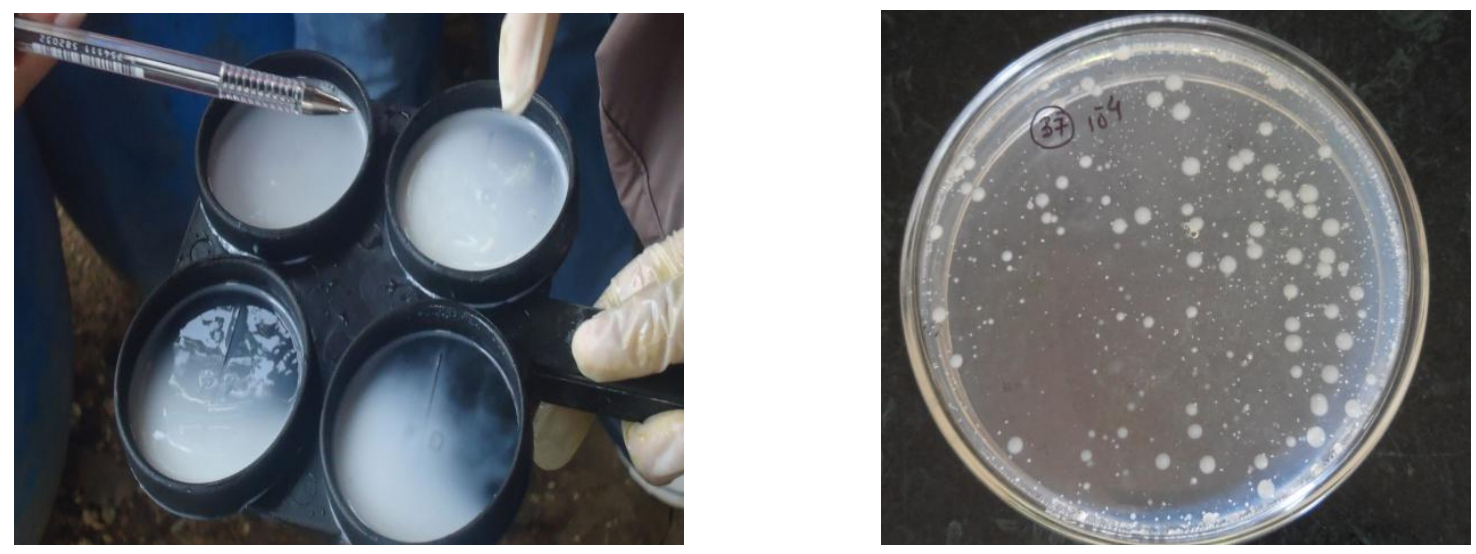
Fig.3

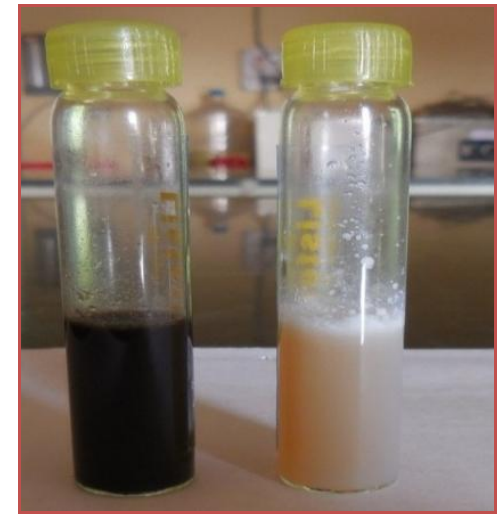

Detection of Listeria

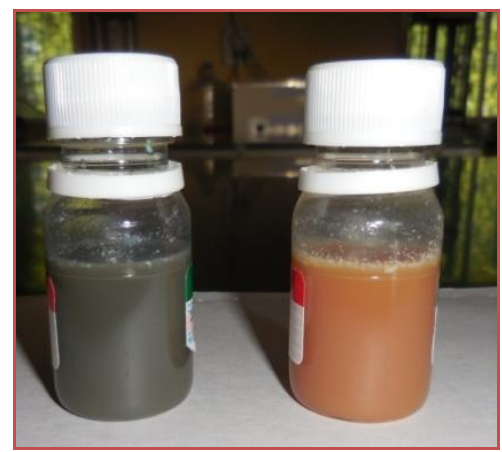

Detection of E. coli

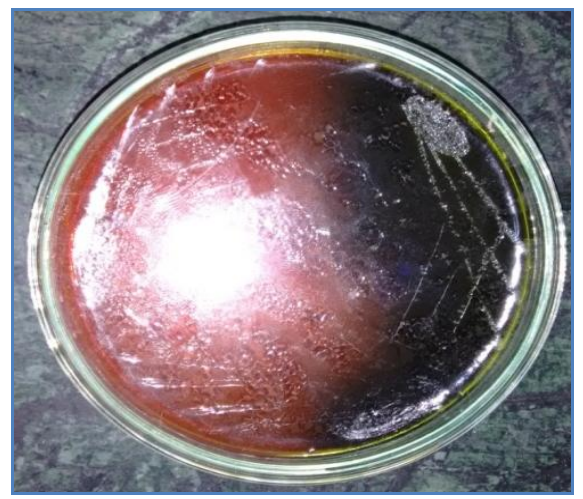

Listeria on PALCAM

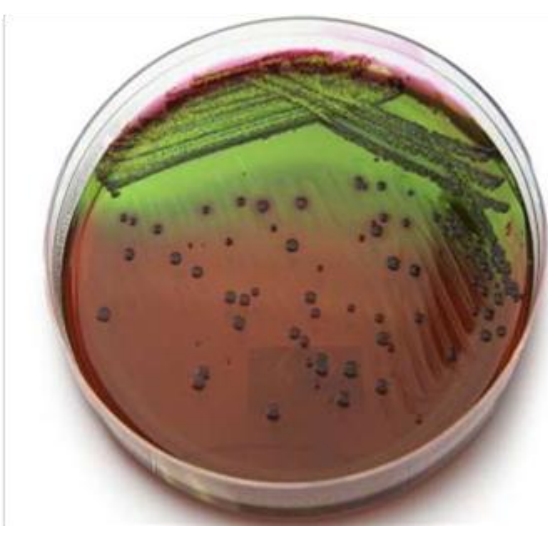

E. coli on EMB agar

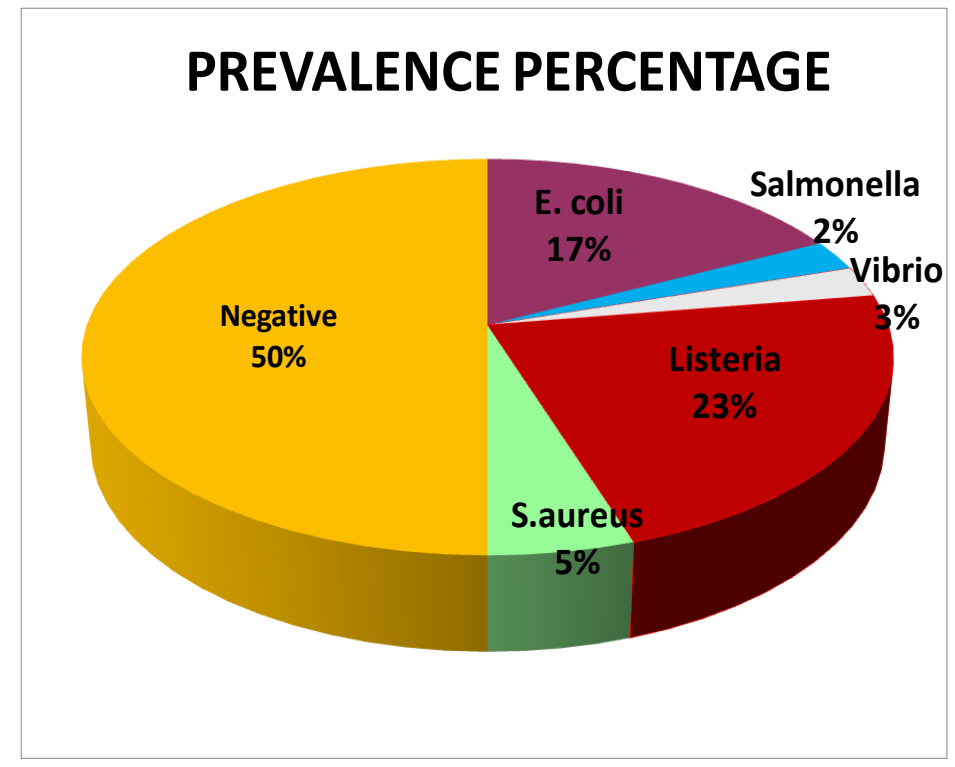


Acidity of milk samples showed significant variation. California mastitis test have been tested by using California mastitis reagent, out of 40 samples 5 samples were positive for CMT test. The total viable count it is under acceptable range. All the samples were negative for the clot on boiling test and methylene blue reduction test. The physiochemical analysis of the milk sample was shown a good relation among MBRT and total viable count. The total viable count determines the microbial load in a sample which develops due to various reasons like contamination of utensils, adulteration of milk with polluted water, milk obtained from diseased cows (mastitis milk). The time taken for the reduction of the dye is influenced by the number and type of bacteria growing in milk and the greater the activity more rapidly the dye reduced. The methylene blue acts as an indicator of bacterial number and activity in raw milk. The sample shown dye reduction time more than $5 \mathrm{hr}$ it means it is the good quality of milk. Positivity for CMT indicates the increase somatic cell count in milk sample it may be because of any disease condition or due to the unhygienic condition at farm level.

\section{Microbiological analysis}

All 40 samples were process for identification different food borne pathogen. The procedures for detection of different food borne are given in the prescribed manual along with the Himedia differential food borne pathogen commercial kit. The entire sample was examined for the $E$. coli, Salmonella, Vibrio, E. coli O157:H7, Listeria monocytogenes, Staphylococcus aureus, and Clostridium spp. Out of all the 40 samples processed for identification of differential food borne pathogen $20(50 \%)$ samples were shown positivity for $E$. coli (7), Salmonella (1), Vibrio (1), Listeria monocytogenes (9), and Staphylococcus aureus (2) suggesting that it could be due to contaminated environment and unhygienic handling or preparation (Table 2). From the above result it is concluded that, a good correlation among MBRT and TVC techniques was observed. The possibility of sources other than microbial sources for mastitis cannot be denied in these cases. the presence of pathogens in milk samples is the matter of concern from public health point of view. Further, the bacterial contamination may be contributed to less hygienic practices followed with respect to udder health management.

\section{Acknowledgement}

The authors gratefully thank the Department of veterinary public health and epidemiology, Nagpur for technical and financial support of this study.

\section{References}

Deb, M. and Seth, D. (2014).Studies on the Physico-Chemical and Microbiological Analysis of Plain Dahi of Assam (India). Journal of Bioresource Engineering and Technology | Year2014 1: 27-32.

Fadaei, A. (2014). Bacteriological quality of raw cow milk in Shahrekord, Iran. Veterinary World. 7(4): 240-243.

FSSAI (2011). Food Safety and Standard Authority of India. Ministry of Health and Family Welfare, published in The Gazette of India.

Han, B., Meng, Y., Li, M., Yang, Y., Ren, F., Zeng, Q., Robert-nout, M.J. (2007). A survey on the microbiological and chemical composition of buffalo milk in china. food control 18(2007) 742-746.

Hossain, M. B. and Dev, S. R. (2013). Physiochemical Characteristics of Various Raw Milk Samples in a Selected Dairy Plant of Bangladesh. International Journal of Engineering and 
Applied Sciences.1 (3): 91-96.

Jain, N. and Shrivastava, S. (2014). Quality Assurance of Marketed Raw Milk in Bhopal city, MP, India. International Research Journal of Biological Sciences. 3(11): 23-27

Nalwaya, S.B., Prajapati, B.I., Bariya, A.R., Goswami, M.M. and Roy, S.K.,2018. Evaluation of Physico-Chemical and Microbiological Quality of Milk of Banaskantha District, India. Int.J.Curr.Microbiol.App.Sci (2018) 7(12): 1635-1641

Rajeev, K. and Amit, P. (2010). Detection of E. coli and Staphylococcus in Milk and
Milk Products in and around Pantnagar. Veterinary World, 2010, Vol.3(11):49549

Ramya, P., Babu, A. J., Reddy, E. T., Reddy, Y. R. and Rao, L. V. (2016). Analysis of various physico chemical properties of raw buffalo milk samples marketed in and around Proddatur town, YSR Kadapa district, Andhra Pradesh, India. Journal of Livestock Science. 7: 30-3

Singh, A. and Pratap, A. (2014). Comparison of Physicochemical Properties of Raw Milk from Indigenous and Exotic Cows at Allahabad. International Journal of Science and Research.3 (8): 1566-156.

\section{How to cite this article:}

Dhote, L.D., G.J. Bidgar, N.R. Pansare, K. Satyaprakash, S.V. Shinde, S.P. Chaudhary, A.R. Patil and Khan, W.A. 2019. Assessment of Physicochemical and Microbiological Quality of Nagpuri Buffalo Raw Milk Collected at Different Areas in Nagpur City. Int.J.Curr.Microbiol.App.Sci. 8(02): 2744-2749. doi: https://doi.org/10.20546/ijcmas.2019.802.321 